\title{
Role of opioid ligands in the irritable bowel syndrome
}

\author{
Enrico Corazziari MD
}

E Corazziari. Role of opioid ligands in the irritable bowel syndrome. Can J Gastroenterol 1999;13(Suppl A):71A-75A. Endogenous opioid peptides - enkephalins, beta-endorphin and dynorphins - are located in specific sites of the brain, the spinal cord, the autonomic ganglia and the enteric nervous system. Endogenous opioids participate in the regulation of nervous visceral afference and sensitivity as well as of several visceral motor function induced by the central nervous system and through the enteroenteric and the myoenteric reflexes. Their final effect on gut physiology is the net and harmonically balanced result of their binding to mu, delta and kappa opioid receptor subtypes. Exogenous opioid receptor ligands with different affinities for the opioid receptor subtypes have been effectively used to modify and normalize altered gut functions. The mu receptor agonists - morphine and, to a greater extent, the meperidine congeners diphenoxylate and loperamide - have been shown to slow gastrointestinal transit by their effects on the circular and longitudinal muscle of the intestine. Diphenoxylate and, more efficiently, loperamide, for the lack of any effect on the central nervous system, have been usefully employed in the treatment of diarrhea in irritable bowel syndrome (IBS) patients. Unlike the mu receptor agonists morphine and loperamide, which invariably stimulate colonic motility, trimebutine, which has almost equal affinity for mu, delta and kappa receptors, has no effect on normal colonic activity but reduces the abnormal increase in postprandial motor activity in IBS patients and accelerates slow large bowel transit in constipated patients. Opioid ligands can be usefully employed to normalize altered visceral sensitivity in IBS patients. The kappa receptor agonist fedotozine exerts its antinociceptive effect by acting on peripheral nerve endings of sensory vagal and nonvagal afferent pathways. Fedotozine has been shown to increase the threshold of perception to colonic distension in experimental conditions and to affect favourably symptoms of IBS in clinical trials.

Key Words: Constipation, Diarrhea, Irritable bowel syndrome, Ligands, Opioids, Receptors

\section{Le rôle des ligands des récepteurs des opiacés dans le syndrome du côlon irritable}

RÉSUMÉ : Les peptides opiacés endogènes, les encéphalines, bêtaendorphines et dynorphines, sont localisés en certains points spécifiques du cerveau, de la moelle épinière, des ganglions autonomes et du système nerveux entérique. Les opiacés endogènes participent à la régulation de l'afférence et de la sensibilité viscérale nerveuse, de même qu'à diverses fonctions motrices viscérales induites par le système nerveux central et par les réflexes entéro-entériques et myo-entériques. Leur effet final sur la physiologie intestinale est l'équilibre harmonieux de leurs liaisons aux sous-types de récepteurs des opiacés mu, delta et kappa. Des ligands des récepteurs des opiacés exogènes présentant des affinités diverses à l'endroit des sous-types de récepteurs des opiacés ont été mis à profit utilement pour modifier et normaliser les anomalies de la fonction intestinale. Les agonistes du récepteur mu, la morphine et, dans une plus large mesure, les proches parents de la mépéridine, le diphénoxylate et le lopéramide, se sont révélés aptes à ralentir le transit gastro-intestinal par des effets sur le muscle circulaire et longitudinal de l'intestin. Le diphénoxylate et, plus efficacement, le lopéramide, dépourvu d'effets sur le système nerveux central, ont été utilisés avec succès dans le traitement de la diarrhée et du syndrome du côlon irritable. Contrairement aux agonistes du récepteur mu, comme la morphine et le lopéramide qui stimulent invariablement la motilité colonique, la trimébutine, qui a une affinité quasi égale à l'endroit des récepteurs mu, delta et kappa, n'exerce aucun effet sur l'activité colonique normale, mais atténue la stimulation excessive de l'activité motrice post-prandiale chez les patients qui souffrent de SCI et accélèrent le transit ralenti du côlon chez les patients constipés. Les ligands des récepteurs des opiacés peuvent être utilisés pour normaliser la sensibilité viscérale anormale chez les patients qui présentent un SCI. L'agoniste du récepteur kappa fédotozine exerce un effet antinociceptif en agissant sur les terminaisons nerveuses périphériques des voies afférentes, vagales et non vagales sensorielles. La fédotozine s'est révélée apte à accroître le seuil de perception de la distension colonique dans des conditions expérimentales et à affecter favorablement les symptômes du SCI lors d'essais cliniques. 


\section{COPYRIGHT PULSUS GROUP ENDOGENOUS OPIOID REGULATION OF GASTROINTESTINAL FUNCTION}

Endogenous opioid peptides - enkephalins, beta-endorphin and dynorphins - are located in specific sites of the brain, the spinal cord, the autonomic ganglia and the enteric nervous system. Their effect on gut physiology is the net and harmonically balanced result of their binding to mu, delta and kappa opioid-receptor subtypes.

Opioids activate a descending inhibitory pathway from the thalamus to the spinal cord and inhibit the ascending pain pathways in the dorsal horn of the spinal cord $(1,2)$. Opioid receptors have been located in the pain pathway, which is concerned with dull, chronic pain, and do not appear to be present in the neospinothalamic pain pathway, which is concerned with sharp, stabbing pain (3). Along the descending inhibitory pathway, opioid receptors have been found in the periaqueductal grey matter, the raphe nuclei and the locus coeruleus $(4,5)$. Along the paleospinothalamic pain pathway, mu, delta and kappa receptors have been found at the level of the spinal cord, the periaqueductal grey matter, the thalamus and the cerebral cortex. In the periphery, opioid receptors have been localized in the myenteric and submucosal plexuses $(6,7)$.

An interesting experimental model that illustrates the complex brain-gut relationship as well as the different effects and sites of actions of the subtypes of opioids is ileus produced by surgical procedure or peritonitis, which elicits pain and gastrointestinal (GI) motor inhibition; the effect on GI motor activity is mediated by a peritoneogastrointestinal inhibitory reflex with the involvement of afferent splanchnic nerves, hypothalamic release of corticotropin-releasing factor (CRF) and efferent vagal fibres. In patients with this condition, both mu and kappa agonists have analgesic effects; however, whereas mu agonists fail to reverse motility and transit alterations, kappa agonists normalize GI motor function. The antinociceptive and the GI motor effects of the kappa agonists are mediated through activation of receptors located on distal ends of visceral primary sensory afferents (8).

In stressful conditions, opioids are involved in modifying behaviour and modulating the hypothalamic neuroendocrine system at the level of the central nervous system (CNS), as well as modifying GI secretomotor activity at the peripheral level. A model that illustrates the role of opioids in the brain-gut connections is the stress-induced delay of the gastric migrating motor complex during prolonged exposure to loud noise in dogs (9). This event is caused by the CNS release of CRF, which affects gastric function through the efferent vagal fibres. After intracerebroventricular administration, kappa, but not mu, agonists abolish the stress-induced lengthening of the gastric migrating motor complex cycle and cortisol increase. After oral and intravenous administration, only kappa agonists block the effect of stress on gastric motility and cortisol increase (9). These studies indicate that kappa opioids may modify and counterbalance the effect of stress on GI function by inhibiting CRF
INC, DO NOT COPY

release at the level of the CNS and by a direct effect on receptors located in the GI tract.

Previous investigations have localized opioid receptors in sensory nerves $(10,11)$, and several studies have reported the role of opioids in the nervous afference from the GI tract $(12,13)$. Both mu and kappa agonists induce antinociception during colonic distension; however, whereas mu agonists act at the level of the CNS, kappa agonists act at the periphery. An electrophysiological study showed that kappa agonists inhibit firing of pelvic afferent fibres before they enter the spinal cord, indicating that kappa ligands act at the periphery on the primary afferent fibres (14).

Afferent fibres of the vagus and splanchnic nerves initiate enterogastric and enteroenteric inhibitory reflexes induced by local distension, and convey sensory stimuli from the GI tract to the CNS. Enterogastric and enteroenteric inhibitory reflexes involve mesenteric ganglia and brain structures, and are modulated by several peripherally and centrally located neuropeptides (15). Distension of the colon and rectum causes gastric and colonic inhibition; these reflexes can be enhanced by emotional stress and mucosal inflammation $(16,17)$. Kappa ligands restore normal gastric motility and emptying that have been inhibited by colonic distension (18); the peripheral action through kappa, but not mu and delta, receptors has been demonstrated by the inhibition of nerve afferent fibre impulses during colonic distension with fedotozine instead of morphine (19). The enhanced afference induced by peripheral inflammation appears to be opposed in physiological conditions by dynorphin and/or enkephalins released from the nervous fibres and the immune cells; in experimental conditions, pharmacological inhibition of afferent fibres during peripheral inflammation has been reported with kappa ligands (20).

$\mathrm{Mu}$ and possibly delta opioids enhance intestinal motor activity by stimulating excitatory nerves, eg, cholinergic ones, and/or blocking the release of neurotransmitter(s) such as vasoactive intestinal peptide, which maintains a tonic inhibition of the smooth muscle $(21,22)$. The sites of action of these opiates may be in the brain, spinal cord, autonomic ganglia and the gut itself. Intracerebroventricular administration of morphine increases intestinal motor activity and delays transit $(23,24)$, and spinal opioid receptors affect GI motility and intestinal transit (25). For example, disconnection between the brain and the sacral centres, as occurs in paraplegic patients, is followed by the loss of the gastrocolonic reflex and slow colonic transit $(26,27)$. Within the GI tract, opioid receptors are located primarily on enteric neurons, and opioid ligands may influence motor function by modulating enteric neural activity. In addition, opioid ligands may release several gut peptides, of which motilin appears to be of great relevance for its ability to induce propagated motor responses in the interdigestive state, via neural mechanism or direct stimulation of mucosal endocrine cells (28). It is likely that, in physiological conditions, endogenous opioids may variably affect GI function on the basis of their affinities for the main subtype receptors, mu, 


\section{COPYRIGHT PULSUS GROUP INC, : DO NOT COPY}

delta and kappa, as well as for different sites along the brain-gut axis and the different levels of the GI tract.

\section{EXOGENOUS OPIOID EFFECT ON GI FUNCTION}

Similar to the effects of endogenous opioid peptides, synthetic opiates may have substantially different effects on GI function as a result of their selectivity for receptor subclasses and site(s) of action. For example, morphine, a selective mu agonist, decreases lower esophageal sphincter pressure, delays gastric emptying, increases resting colonic motor activity, has an antinociceptive effect and does not affect postsurgical ileus motor activity; its action is more effectively mediated through mu receptors located in the CNS. Fedotozine, a selective kappa agonist, does not affect lower esophageal sphincter pressure, gastric emptying and resting colonic motility; has an antinociceptive effect; and reverts postsurgical ileus motor activity; its action is more effectively mediated through kappa receptors located in the periphery, outside of the CNS. Trimebutine, with an almost equal affinity for mu, delta and kappa receptors, increases lower esophageal sphincter pressure, delays gastric emptying, has no effect on resting colonic motility, has no antinociceptive effect and shortens the postsurgical ileus motor activity, and its action is more effectively mediated through all three main receptor subtypes located in the periphery, outside of the CNS.

The final effect of an opioid ligand on the GI tract also depends on the functional state and degree of activity of the GI sensory-secretory-motor function during which it is administered. Likewise, its final effect may be different in the presence of disease processes that may alter the functional state of the GI tract and neuromodulation of opioid receptors. It follows that the effects of opioid ligands in patients are not predictable on the basis of their action in healthy subjects, and, according to their affinities for subtype receptors, they may be used in a variety of different, and even opposite, pathological conditions.

Some of the GI effects of opium derivatives have been so well known for such a long time that Arabian physicians employed opium to treat dysentery more than 1000 years ago. More recently, the identification of opioid ligands that affect GI function through peripheral opioid binding sites without involvement of the CNS and with no neurological and psychological side effects has led to the development of synthetic opioid peptides devoted to the control of several conditions of altered GI dysfunctions such as functional dyspepsia, noncardiac chest pain, irritable bowel syndrome (IBS), functional chronic diarrhea and chronic constipation.

\section{OPIOID TREATMENT OF FUNCTIONAL BOWEL DISORDERS}

Functional chronic diarrhea: Among the mu agonists, the piperidine derivatives diphenoxylate and loperamide have been used to treat diarrhea because of their definite constipating effect. They have a potent motor effect consisting of a decrease in propulsive contractions and an increase in ampli- tude and frequency of nonpropulsive segmental contractions. They also increase the tone at all levels of the GI tract (29).

At the level of the GI tract, these mu agonists exert their antisecretory effects on the submucosal plexus, which reduces basal secretion of enterocytes and inhibits the stimulatory action of secretory transmitters such as acetylcholine, prostaglandin $\mathrm{E}_{2}$ and vasoactive intestinal peptide. Aside from inhibiting intestinal secretion, the mu agonists inhibit biliary and pancreatic secretions, thus reducing endoluminal fluid accumulation (30). The increased resistance to content displacement by segmental contractions and the reduced aboral propagation by the inhibition of peristaltic activity combined with reduced intraluminal secretion slow GI transit and increase the viscosity of bowel contents, which induces constipation in healthy subjects and controls bowel movements in patients with diarrhea. Of the two piperidine derivatives, diphenoxylate is not totally devoid of morphine-like physical dependence after chronic administration, whereas loperamide, which is as effective as diphenoxylate in the control of diarrhea, can be used for chronic treatment with no central side-effects.

In patients with IBS, a double-blind, placebo controlled crossover study showed that loperamide was effective in relieving diarrhea, urgency and borborygmi; small bowel and whole gut transit time was delayed, while stool frequency and the proportion of unformed stools were reduced, with no reduction in stool weight (31). IBS patients complaining of diarrhea as their predominant symptom have a normal daily stool output (ie, less than $200 \mathrm{~g}$ ), have frequent and loose motions, and suffer from urgency and incontinence (32). It is likely that the entry of even small volumes of unformed feces in the rectum is facilitated by a reduction in segmenting nonpropagated sigmoid motor activity (33); the associated lowered threshold of reflex contraction causes the rectum to contract spasmodically to even small amounts of feces, giving rise to symptoms of urgency, increased frequency of movements and episodes of incontinence.

In patients with diarrhea and fecal incontinence, loperamide reduced the episodes of incontinence and increased the compliance of the rectosigmoid tract (34).

Functional constipation: Functional constipation (35) may be due to slow colonic transit and/or alteration of the defecatory mechanism. Slow transit constipation may be caused by two factors - decreased numbers of peristaltic contractions in the colon (36) and/or increased number of segmenting nonpropagating contractions in the sigmoid colon (33). The latter condition is often associated with abdominal pain and pellet-like feces, and is regarded as one of the clinical manifestations of IBS.

The nonselective opioid agonist trimebutine, with its almost equal affinity for peripherally located mu, delta and kappa receptors, has no effect on the motor activity of the sigmoid colon in healthy subjects, in both the fasted and fed states $(37,38)$. On the contrary, it has been reported to decrease the meal-induced sigmoid hypermotility (38) and to increase the number of propagated spike bursts (39) in constipated IBS patients. Two double-blind, placebo controlled 
COPYRIGHT PULSUS GROUP

studies reported that trimebutine oral administration for up to two months significantly improved clinical symptoms and shortened colonic transit time in constipated IBS patients $(39,40)$.

IBS: The key clinical expression of IBS, as indicated in a recent definition by an international consensus panel (35), is abdominal pain or discomfort variably associated with any of several different bowel dysfunctions. The pathophysiology of IBS has so far defied investigators, and no single factor has been convincingly proven to offer a plausible explanation for the different and variably presenting symptoms. Several motor abnormalities affecting the small and/or the large bowel have been reported in IBS patients, but none has been consistently associated with symptoms. In addition, treatments capable of reverting motor dysfunctions have a limited effect on abdominal pain.

A large body of evidence has recently accumulated to indicate that altered visceral perception is present in IBS patients and is considered by some investigators to be the hallmark of this syndrome.

In a double-blind, placebo controlled trial, the kappa agonist fedotozine, at a dose of $30 \mathrm{mg}$ tid, induced a significant decrease in the intensity of daily abdominal pain and of the painless days. Bloating was also significantly improved by fedotozine. The benefit of the kappa agonist therapy was also evident as a significant improvement of the overall treatment efficacy (41).

Another double-blind, placebo controlled clinical trial confirmed the favourable effect of fedotozine $30 \mathrm{mg}$ tid on the symptomatic relief of abdominal pain in IBS patients and significantly improved quality of life (42).

Synthesis: Different opioid receptors located at several sites along the brain-gut axis participate in the regulation of the function of the GI tract.

Development of specific subtypes of opioid ligands that act at the periphery and are devoid of any effect on the CNS can be usefully employed to treat the various manifestations of functional bowel disorders such as chronic diarrhea, constipation and visceral hypersensitivity of the IBS.

\section{REFERENCES}

1. Koob GF, Bloom FE. Behavioural effects of opioid peptides. Br Med Bull 1983;39:89-94.

2. Basbaum AI, Fields HL. Endogenous pain control systems: brainstem spinal pathways and endorphin circuitry. Ann Rev Neurosci 1984;7:309-38.

3. Jessell TM, Kelley DD. Pain and analgesia. In: Kandel ER, Schwartz JH, Jessell TM, eds. Principles of Neural Science, 3rd edn, New York: Elsevier, 1991:385-99.

4. Jones SL, Gebhart GF. Inhibition of spinal nociceptive transmission from the midbrain, pons and medulla in the rat. Brain Res 1988:460:281-96.

5. Mansour A, Fox CA, Akil H, et al. Opioid-receptor mRNA expression in the rat CNS: anatomical and functional implications. Trends Neurosci 1995;18:22-9.

6. Larsson LI, Stenagaard-Pederson K. Immunocytochemical and ultrastructural differentiation between met-enkephalin, leu-enkephalin and met/leu enkephalin immunoreactive neurons of feline gut. J Neurosci 1982;2:861-78.

7. Costa M, Furness JB, Gibbons IL, Murphy R. Chemical coding and projections of opioid peptide containing neurons in the guinea pig intestine. Neurosci Lett 1985;22:S19-55.

8. Rivière PJM, Pascaud X, Chevalier E, Le Gallon B, Junien JL.
NNC. DO NOT COPY

by surgery or peritonitis: action at peripheral kappa opioid receptors. Gastroenterology 1993;104:724-31.

9. Gué M, Honde C, Pascaud X, et al. CNS blockade of acoustic stress-induced gastric motor inhibition by k-opiate agonists in dogs. Am J Physiol 1988;254:G802-15.

10. Hassan AHF, Abletiner A, Stein C, Herz A. Inflammation of the paw enhances axonal transport of opioid receptors in the sciatic nerve and increases their density in the inflamed tissue. Neuroscience 1993;55:185-95.

11. Laduron P. Axonal transport of opiate receptors in capsaicin sensitive neurones. Brain Res 1984;294:157-60.

12. Diop L, Rivière P, Pascaud X, Dassaud M, Junien JL. Role of vagal afferents in the antinociception produced by morphine and U-50, $488 \mathrm{H}$ in the colonic pain reflex in rats. Eur J Pharmacol 1994;257:181-7.

13. Langlois A, Diop L, Rivière PJM, Junien JL. Fedotozine inhibits abdominal constrictions induced by colonic distension during colonic hypersensitivity in conscious rats. Neurogastroenterol Motil 1994;6:140.

14. Sengupta JN, Gebhart GF. Effect of kappa opioid receptors agonists on mechanosensitive pelvic nerve afferent fibers innervating the colon of the rat. Gastroenterology 1995;108:A686. (Abst)

15. Fargeas MJ, Fioramonti J, Bueno L. Central action of interleukin-1 $\beta$ on intestinal motility in rats, mediation by two mechanisms. Gastroenterology 1993;104:377-83.

16. Bueno L. Brain-gut mechanisms of visceral motor activity. In: Corazziari E, ed. NeUroGastroenterology. Berlin: De Gruyter, 1995:1-16.

17. Julia V, Mezzasalma T, Bueno L. Influence of bradykinin in gastrointestinal disorders and visceral pain induced by acute or chronic inflammation in rats. Dig Dis Sci 1995;40:1913-21.

18. Gué M, Bueno L. Fedotozine modulates colonic distension-induced inhibition of gastric motility and emptying in dogs. In: Galmiche JP, Fraitag B, eds. Sensitive Gastrointestinal Disorders. London: John Libbey, 1995:55-63.

19. Gebhart GF, Sengupta JN. Effects of fedotozine on mechanosensitive pelvic nerve afferent fibres in rat. In: Galmiche JP, Fraitag B, eds. Sensitive Gastrointestinal Disorders. London: John Libbey, 1995:65-71.

20. Haley J, Ketchum S, Dickenson A. Peripheral kappa-opioid modulation of the formalin response: an electrophysiological study in the rat. Eur J Pharmacol 1990;191:437-46.

21. Fox JET, Daniel EE. Exogenous opiates: Their local mechanisms of action in the canine small intestine and stomach. Am J Physiol 1987;253:G179-88.

22. Manaka H, Manaka Y, Kostolanska F, Fox JET, Daniel EE. Release of VIP and substance $P$ from isolated perfused canine ileum. Am J Physiol 1989;257:G182-90.

23. Stewart JJ, Weisbrodt NW, Burks TF. Centrally mediated intestinal stimulation by morphine. J Pharmacol Exp Ther 1977;202:174-81.

24. Stewart JJ, Weisbrodt NW, Burks TF. Central and peripheral actions of morphine on intestinal transit. J Pharmacol Exp Ther 1978;205:547-55.

25. Porreca F, Filla A, Burks TF. The spinal cord-mediated opiate effects on gastrointestinal transit in mice. J Pharmacol Exp Ther 1983;227:22-7.

26. Glick ME, Meshkinpour H, Haldeman S, et al. Colonic dysfunction in patients with thoracic spinal cord injury. Gastroenterology 1984;86:287-94.

27. Menardo G, Bausano G, Corazziari E, et al. Large bowel transit in paraplegic patients. Dis Colon Rectum 1987;30:924-8.

28. Champion MC, Sullivan SN, Bloom SR, Adrian TE, Christofides NS. The effects of naloxone and morphine on postprandial gastrointestinal hormone secretion. Am J Gastroenterol 1982;77:617-20.

29. Manara L, Bianchetti A. The central and peripheral influences of opioids on gastrointestinal propulsion. Ann Rev Pharmacol Toxicol 1985;25:249-73.

30. Kromer W. Endogenous and exogenous opioids in the control of gastrointestinal motility and secretion. Pharmacol Rev 1988;40:121-62.

31. Cann PA, Read NW, Holdsworth CD, Barends D. Role of loperamide and placebo in management of irritable bowel syndrome (IBS). Dig Dis Sci 1984;29:239-47.

32. Cann PA, Read NW, Holdsworth CD. Irritable bowel syndrome: 
relationship of disorders in the transit of a single meal to symptom patterns. Gut 1983;24:405-11.

33. Connell AM. Motility of the pelvic colon. Part II. Paradoxical motility in diarrhea and constipation. Gut 1962;3:342-8.

34. Read MG, Read NW, Barber DC, Duthie HL. Effects of loperamide on anal sphincter function in patients complaining of chronic diarrhea with fecal incontinence and urgency. Dig Dis Sci 1982;27:807-14.

35. Thompson WG. Functional bowel disorders. In: Drossman DA, Talley NI, Thompson WG, Corazziari E, Whitehead WE, eds. The Functional Gastrointestinal Disorders. Boston: Little Brown, 1994:115-74.

36. Bassotti G, Gaburri M, Imbimbo BP, et al. Colonic mass movements in idiopathic chronic constipation. Gut 1988;29:1173-9.

37. Valori R, Shannon S, Reddy N, Daniel EE, Collins SM. The action of trimebutine maleate on gastrointestinal motility is mediated by opiate receptors in human subjects. Gastroenterol Clin Biol 1987;11:102B-4B.
NNG = DO NOT COPY

38. Shannon S, Hollingsworth J, Cook IJ, Collins SM. Effect of trimebutine on postprandial colonic motor activity in healthy subjects and patients with irritable bowel syndrome. J Gastroenterol Motil 1989;1:9-14.

39. Schang JC, Devroede G, Pilote M. Beneficial effects of trimebutine in patients suffering from irritable bowel disease (IBS) with normal transit or constipation. Gastroenterology 1988;94:A403. (Abst)

40. Moshal MG, Herron M. A clinical trial of trimebutine (Mebutin) in spastic colon. J Int Med Res 1979;7:2331-4.

41. Dapoigny M, Abitbol JL, Fraitag B. Efficacy of peripheral kappa agonist fedotozine versus placebo in treatment of irritable bowel syndrome. A multicenter dose-response study. Dig Dis Sci 1995;40:2244-8

42. Dapoigny M, Abitbol JL, Meric G, Geneve G, Fraitag B. Fedotozine in irritable bowel syndrome: results of a $6 \mathrm{wk}$ placebo-controlled multicenter therapeutical trial. Gastroenterology 1995;108:A588. (Abst) 


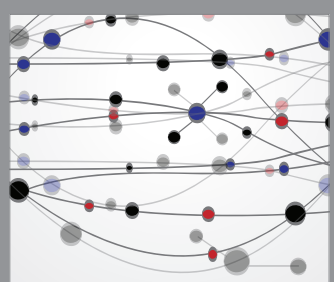

The Scientific World Journal
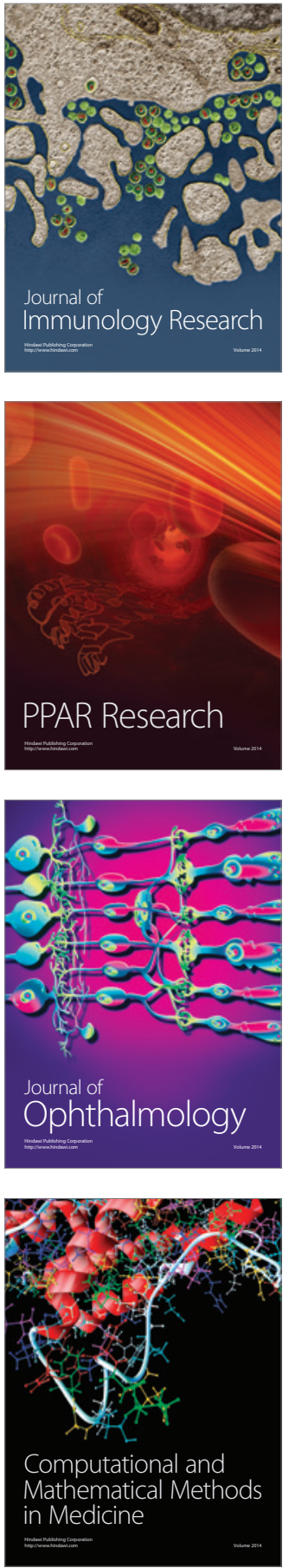

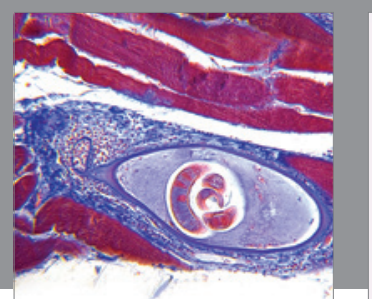

Gastroenterology Research and Practice

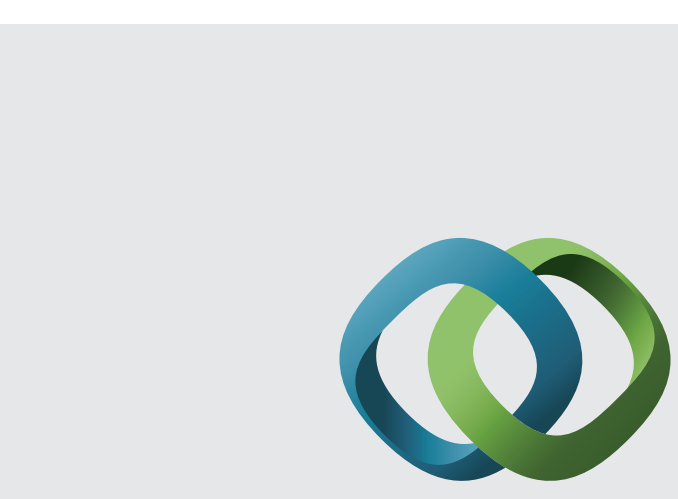

\section{Hindawi}

Submit your manuscripts at

http://www.hindawi.com
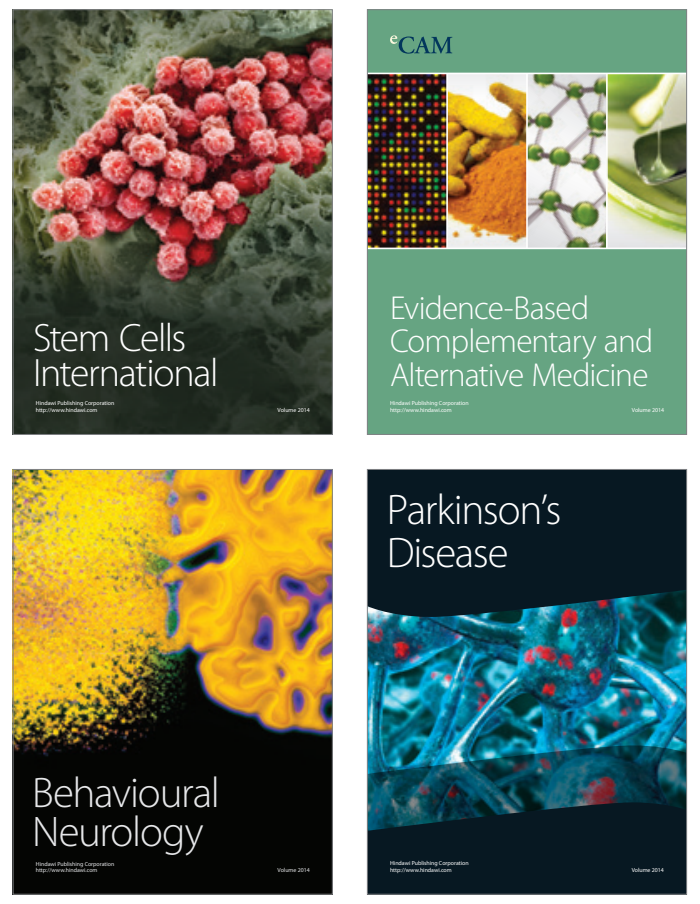
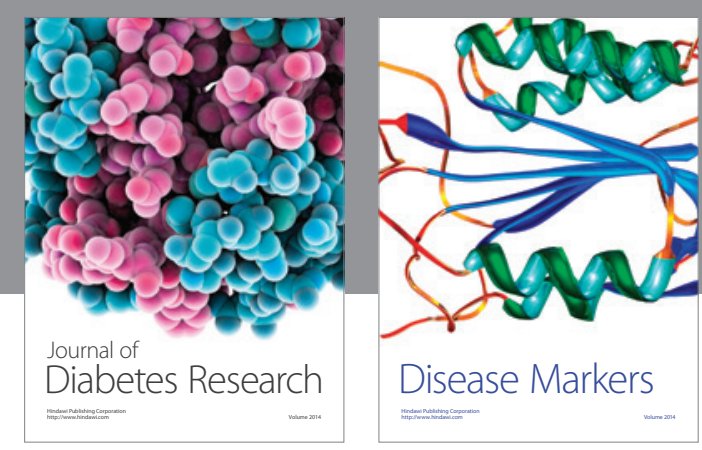

Disease Markers
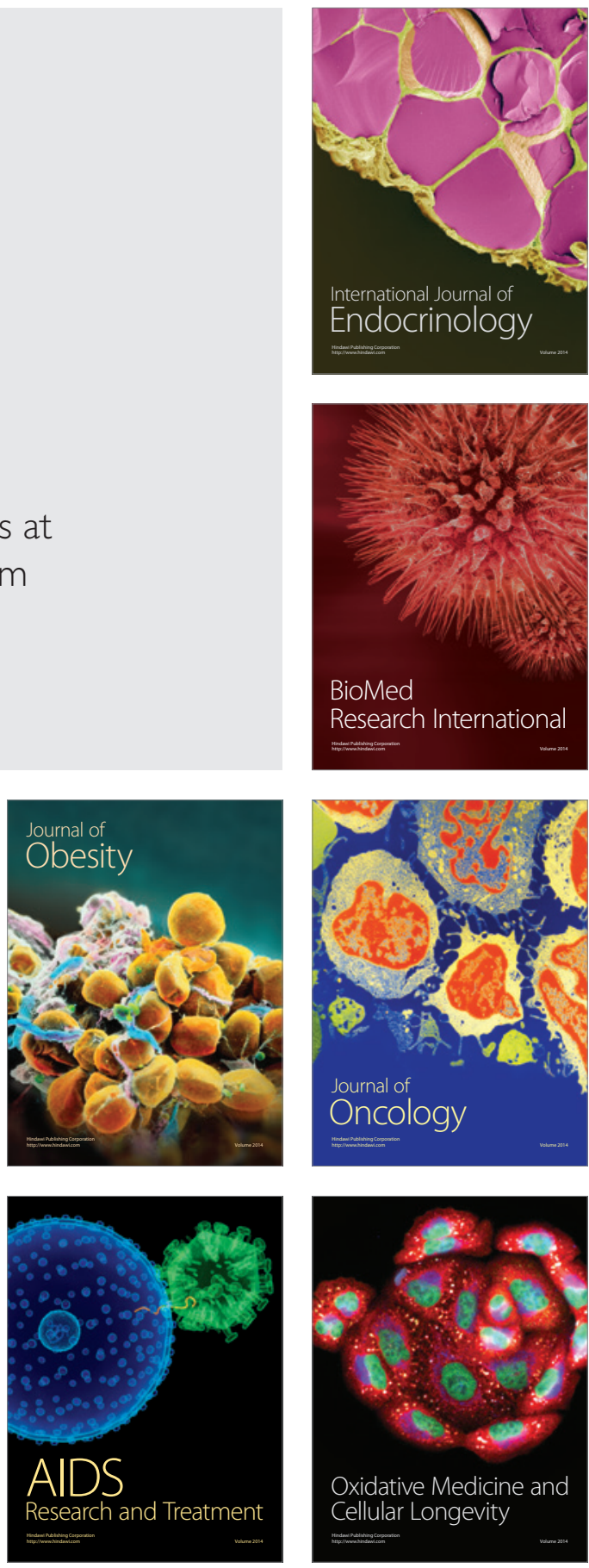